\title{
Preterm birth among women living within 600 meters of high voltage overhead Power Lines: a case-control study
}

\author{
TAKTOM SADEGHI ${ }^{1}$, AMIRMASOUD AHMADI ${ }^{2}$, MARYAM JAVADIAN $^{3}$, SAYYED ASGHAR GHOLAMIAN $^{4}$, \\ MOULOUD AGAJANI DELAVAR ${ }^{3}$, SEDIGHEH ESMAILZADEH ${ }^{3}$, BAHARE AHMADI $^{5}$, \\ MOZHGAN SADAT HASSANPOUR HADIGHI ${ }^{6}$ \\ ${ }^{1}$ Department of Obstetrics and Gynecology, Babol University of Medical Sciences, Babol, Iran \\ ${ }^{2}$ Biomedical Engineering Biomedical Engineering Department, Faculty of Electrical Engineering, \\ Iran University of Science and Technology (IUST), Tehran, Iran \\ ${ }^{3}$ Infertility and Reproductive Health Research Center, Department of Obstetrics and Gynecology, \\ Babol University of Medical Sciences, Babol, Iran \\ ${ }^{4}$ Faculty of Electrical and Computer Engineering, Babol University of Technology, Babol, Iran \\ ${ }^{5}$ Electronic Engineering, Mazandaran Regional Electric Company, Sari, Iran \\ ${ }^{6}$ Rouhani Hospital, Department of Obstetrics and Gynecology, Babol University of Medical Science, Babol, Iran
}

\begin{abstract}
Aim. The issue of preterm birth due to exposure to magnetic fields from power lines is unclear. Exposure to electromagnetic field in uterus has been hypothesized as possible preterm birth. The aim of the present study was to determine whether living closer to high voltage power lines increased the risk of preterm labor.

Methods. In a nested case-control study, 135 cases of singleton live spontaneous preterm birth in Rohani hospital, Babol, Iran, during the period between 2013 and 2014 were studied. The 150 control subjects were singleton term live birth in the same year of birth and city of residence using randomized-digit dialing. The shortest distance to any of the high voltage power lines to the maternal residence during pregnancy was measured using ArcGIS software for every case and control. To test the association between the preterm births and the residential proximity to power lines, stepwise multiple logistic regression was used.

Results. There were 28 households, 20 cases $(14.8 \%)$ and 8 controls $(5.3 \%)$ situated within 600 meters of high voltage power lines. The adjusted OR for spontaneous preterm birth and birth defect in women who were living in less than 600 meters from high voltage power lines was higher compared to those living at farther distance $(\mathrm{OR}=3.28, \mathrm{CI}$ : 1.37 to 7.85$)$ and $(\mathrm{OR}=5.05, \mathrm{CI}: 1.52$ to 16.78), respectively.

Conclusions. Therefore, installing overhead power lines and stations within 600 meters or making overhead underground would be useful in the prevention of both preterm birth and birth defect.
\end{abstract}

Key words: electric power supplies, premature birth, congenital abnormalities, environmental exposure, geographic information systems.

\section{INTRODUCTION}

Despite the progress in antenatal care service in all countries, the rate of preterm birth is increasing in developed and developing countries, especially Iran [1]. The prevalence of preterm birth in Iran is $9.2 \%$ [2]. A possible reason for this could be that the fetus has been shown to be vulnerable to environmental exposures during pregnancy [3].

The main transmission grids in Iran are the overhead lines, rating at 400 and 230, and $60 \mathrm{kV}$. In Mazandaran and Golestan Province, Iran, a total of 1229 kilometers of $400 \mathrm{kV}, 1314$ kilometers of $230 \mathrm{kV}$ overhead transmission lines were introduced to the environment as a result of increasing demand for reliable and renewable energy supplies. These power line routes may have a considerable impact on the residents living nearby. Many research studies regarding the impact of low frequency electromagnetic fields on residents living close to very high voltage overhead power lines were carried out. Most studies were done on the occurrence of malignancy in both children and adults [4-12]. A review study has shown that childhood leukemia is associated with exposure to magnetic field [13]. Many other studies were also carried out with regard to the effects of low frequency electromagnetic fields on reproductive outcomes and birth defect. These studies suggest the role of this exposure and the increased risk of birth defect $[14,15]$. In addition, the results from some studies have indicated that exposure to magnetic field may be associated with the increased risk of adverse birth outcomes such as low birth weight [16] and miscarriages [17]. Some studies, however, did not find a statistically significant increased risk of preterm birth and low 
birth weight in relation to exposure to electromagnetic field during pregnancy $[18,19]$ reproductive outcomes [14]. Pregnant women in Iran sometimes live very close to very high voltage overhead power lines and are exposed to electromagnetic fields [11]. Most residents living in close proximity to overhead power lines are more concerned about the outcome of their pregnancy [20]. The scientific evidence for other outcomes of pregnancy such as preterm birth is quite weak. A recent study from Iran suggests that magnetic fields do not cause the preterm birth among mothers living close to power lines during pregnancy [21], and it does not have the power to exclude the risk of preterm birth. In the present study, we tested the hypothesis that close proximity to maternal residential exposure to magnetic fields from power lines could be associated with the increased spontaneous preterm birth. To this end, we analyzed 135 mothers with preterm birth, and 150 matched controls, who were residents in Babol, in north Iran. We tried to find out if there were any associations between the preterm birth and these lines as a risk factor.

\section{MATERIAL AND METHODS}

In this nested case-control study, 155 diagnosed spontaneous preterm births from within a birth registry in Rohani Hospital affiliated to Babol University of Medical Sciences, during the period between Feb. 2013 and Dec. 2014, were studied. The 155 control subjects were chosen using randomized-digit dialing, which was matched for the child birth year and the city of residence. Out of 155 eligible cases, 20 women were excluded from the study due to their non-precise addresses. Five addresses were also missing for women in the control group. Thus, no distance was recorded for 25 subjects ( 20 cases, 5 controls), which excluded them from the statistical analyses.

This study was approved by Babol University of Medical Sciences for ethics in medical research. Written informed consents were obtained from all participants in this study. Spontaneous preterm birth was defined as less than 37 weeks of completed gestation, excluding the elective cesarean section. The gestational age was also referred to as the last missed period (LMP) data and/or the scanned data during early pregnancy and the modified Ballard gestational age after birth according to their medical records. The birth defect types, included in the analyses, were: central nervous system (CNS) defects, cardiac defects, respiratory system defects, oesophageal defects, and clubfoot by the patients file [14]. Newborn death during 24 hours of birth was considered in both groups.

The required sample size for each group was calculated to be 152 , using a confidence level of $95 \%$, the expected proportion exposed in controls of 0.05 , power of 0.8 , and the assumed odds ratio of 3.2. A check list focusing on birth outcome and obstetric history was administered in all patients' file. The maternal age, which was between 16 to 40 , was categorized into three groups: $<25$ years, 25-35 years, and $>35$ years. Age at marriage was categorized $<20$ years, 20-25 years, and $>25$ years. The residence of mother during pregnancy was dichotomized into urban and rural. Parity was also coded as no birth, one previous birth, and two previous births. The maternal smoking data were recorded as 'yes/no', but because it was not reported by anyone, this was not included in the statistical models. The Apgar score at 60 seconds after the birth of the newborn was categorized into two groups: $<7$ and $\geq 7$. After obtaining the geographical data related to cables, lines, and electricity towers, we measured the nearest linear distance from the high voltage power lines to the maternal residence during pregnancy using ArcGIS software for every case and control. The women in the both groups, preterm and term birth, were categorized into two groups: women living $<600$ meters from power lines and $\geq 600$ meters $[4,6,11]$. The confounding variables were parity, the educational status of men and women, and the job of men and women.

\section{STATISTICAL ANALYSIS}

All data analyses were conducted through SPSS Version 18.0 (Inc., Chicago, IL, USA). The status of pregnancy outcome for exposure and nonexposure to electro-magnetic field groups was compared using descriptive and $\chi^{2}$ statistics. To test the association between the preterm births and the residential proximity to power lines, bivariate conditional logistic regression analyses at $\mathrm{P}=0.2$ were used. Odd ratios (ORs) were assessed using the maximum likelihood, and the associated 95\% confidence intervals (CIs) were computed. A p value of 0.05 or less was considered significant.

\section{RESULTS}

A total of 285 women with a mean age of $27.5 \pm 5.5$ years participated in the study. The cases consisted of 135 women with spontaneous preterm birth, 44 urban (32.6\%), 91 rural $(67.4 \%), 125$ house work (92.6\%), 72 nulliparous $(53.8 \%)$, with a mean 
age of $21.3 \pm 4.8$. The randomly selected controls included 150 women with term birth, 52 urban (34.7\%), 98 rural (65.3\%), 140 house work (93.3\%), 73 nulliparous $(78.7 \%)$, with a mean age of $21.5 \pm$ 4.6 years (Table 1). Most of women with spontaneous preterm delivery (64.4\%) had emergency cesarean. Type of delivery was different between those with preterm birth compared to those with term birth. However, in order to accurately assess spontaneous preterm labor those with elective cesarean were previously excluded from the case group. Percentages of Apgar $<7$ at one minute in women with preterm birth were significantly more compared to those with term birth $(8.1 \%$ vs $0 \%, \mathrm{p}=0.0001)$. A significant statistical difference was found in birth weight $(p=0.0001)$, birth defect $(p=0.023)$, and newborn death during 24 hours of birth $(p=0.0001)$ between women with preterm and term birth (Table 2).

Table 1

Characteristics of participants in cases of preterm birth and control groups

\begin{tabular}{|c|c|c|c|}
\hline & $\begin{array}{l}\text { Total (285) } \\
\text { N }(\%)\end{array}$ & $\begin{array}{c}\text { Preterm birth }(\mathrm{n}=135) \\
\mathrm{N}(\%)\end{array}$ & $\begin{array}{c}\text { Term birth }(\mathrm{n}=150) \\
\mathrm{N}(\%)\end{array}$ \\
\hline \multicolumn{4}{|l|}{ Age (years) } \\
\hline$<20$ & $112(39.3)$ & $51(37.8)$ & $61(40.7)$ \\
\hline $20-35$ & $152(53.3)$ & $74(54.8)$ & $78(52.0)$ \\
\hline$>35$ & $21(7.4)$ & $10(7.4)$ & $11(7.3)$ \\
\hline \multicolumn{4}{|c|}{ Age of marriage (years) } \\
\hline$<20$ & $140(49.1)$ & $71(52.6)$ & $69(46.0)$ \\
\hline $25-25$ & $98(34.4)$ & $44(32.6)$ & $54(36.0)$ \\
\hline$>25$ & $47(16.5)$ & $20(14.8)$ & $27(18.0)$ \\
\hline \multicolumn{4}{|c|}{ Years of education completed } \\
\hline$<6$ & $38(13.3)$ & $20(14.8)$ & $18(12.0)$ \\
\hline $6-12$ & $185(64.9)$ & $84(62.2)$ & $101(67.3)$ \\
\hline$>12$ & $62(21.8)$ & $31(23.0)$ & $31(20.7)$ \\
\hline \multicolumn{4}{|l|}{ Residence } \\
\hline Urban & $96(33.7)$ & $44(32.6)$ & $52(34.7)$ \\
\hline Rural & $189(66.3)$ & $91(67.4)$ & $98(65.3)$ \\
\hline \multicolumn{4}{|l|}{ Own occupation } \\
\hline Housewife & $265(93.0)$ & $125(92.6)$ & $140(93.3)$ \\
\hline Work outside & $20(7.0)$ & $10(7.4)$ & $10(6.7)$ \\
\hline \multicolumn{4}{|l|}{ Age of husband } \\
\hline$<25$ & 13(4.6) & $8(5.9)$ & $5(3.3)$ \\
\hline $25-35$ & $203(71.2)$ & $91(67.4)$ & $112(74.7$ \\
\hline$>35$ & $69(24.2)$ & $36(26.7)$ & $33(22.0)$ \\
\hline \multicolumn{4}{|c|}{ Husband occupation } \\
\hline Clerk & $245(86.0)$ & $114(84.4)$ & $131(87.3)$ \\
\hline Non clerk & $40(14.0)$ & $21(15.6)$ & $19(12.7)$ \\
\hline \multicolumn{4}{|l|}{ Parity } \\
\hline none & $145(50.9)$ & $72(53.3)$ & $73(48.7)$ \\
\hline 1 & $103(36.1)$ & $49(36.3)$ & $54(36.0)$ \\
\hline$\geq 2$ & $37(13.0)$ & $14(10.4)$ & $23(15.3)$ \\
\hline \multicolumn{4}{|l|}{ History abortion } \\
\hline no & $230(80.7)$ & $107(79.3)$ & $123(82.0)$ \\
\hline yes & $55(19.3)$ & $28(20.7)$ & $27(18.0)$ \\
\hline \multicolumn{4}{|l|}{\begin{tabular}{|l|} 
History IUFD \\
\end{tabular}} \\
\hline no & $282(98.9)$ & $133(98.5)$ & $149(99.3)$ \\
\hline yes & $3(1.1)$ & $2(1.5)$ & $1(0.7)$ \\
\hline \multicolumn{4}{|c|}{ History preterm birth } \\
\hline no & $276(96.8)$ & $130(96.3)$ & $147(98.0)$ \\
\hline yes & $9(3.2)$ & $5(3.7)$ & $3(2.0)$ \\
\hline \multicolumn{4}{|c|}{ History Low birth weight } \\
\hline no & $272(95.4)$ & $126(93.3)$ & $146(97.3)$ \\
\hline yes & $13(4.6)$ & $9(6.7)$ & $4(2.7)$ \\
\hline \multicolumn{4}{|c|}{ Distances from power lines } \\
\hline$<600$ meters & $28(9.8)$ & $20(14.8)$ & $8(5.3)$ \\
\hline$\geq 600$ & $257(90.2)$ & $115(85.2)$ & $142(94.7)$ \\
\hline \multicolumn{4}{|l|}{ Sex of baby } \\
\hline Female & $155(54.4)$ & $70(51.9)$ & $85(56.7)$ \\
\hline Male & $130(45.6)$ & $65(48.1)$ & $65(43.3)$ \\
\hline
\end{tabular}

${ }^{\dagger}$ : Intra Uterine Fetal Death 
Table 2

Selected birth outcomes among case and control groups

\begin{tabular}{|c|c|c|c|}
\hline & $\begin{array}{c}\text { Preterm birth }(\mathrm{n}=135) \\
\text { N }(\%)\end{array}$ & $\begin{array}{c}\text { Term birth }(\mathrm{n}=150) \\
\mathrm{N}(\%)\end{array}$ & P-values \\
\hline \multicolumn{4}{|l|}{ Type of delivery } \\
\hline vaginal & $48(35.6)$ & $50(33.3)$ & 0.0001 \\
\hline Emergency cesarean & $87(64.4)$ & $48(32.0)$ & \\
\hline Elective cesarean ${ }^{\dagger}$ & $0(0.0)$ & $52(34.7)$ & \\
\hline \multicolumn{4}{|l|}{ Birth weight $(\mathrm{kg})$} \\
\hline$<2500$ & $70(51.9)$ & $5(3.3)$ & 0.0001 \\
\hline $2500-3900$ & $65(48.1)$ & $133(88.7)$ & \\
\hline$>3900$ & $0(0.0)$ & $12(8.0)$ & \\
\hline Apgar $<7$ score at one minute & $11(8.1)$ & $0(0.0)$ & 0.0001 \\
\hline Birth defect & $12(8.9)$ & $4(2.7)$ & 0.023 \\
\hline Newborn death during 24 hours of birth* & $11(9.1)$ & $0(0.0)$ & 0.0001 \\
\hline
\end{tabular}

${ }^{\dagger}$ Intra Uterine Fetal Death (IUFD) and preterm with elective cesarean were mutually exclusive.

Most women ( $\mathrm{n}=257,115$ cases, 142 controls) lived in homes, which were not located near high voltage power lines. There were 28 households, 20 cases $(14.8 \%), 8$ controls $(5.3 \%)$ were situated within 600 meters of a high voltage power lines.

After adjusting for possible confounding variables including parity, residence, educational status of men and women, and the job of men and women, it was found that women who were living in less than 600 meters from high voltage power lines had spontaneously higher preterm birth $(\mathrm{OR}=$ 3.28 , CI: 1.37 to 7.85$)$ and higher birth defects $(\mathrm{OR}=$ 5.05, CI: 1.52 to 16.78$)$ compared to those living at farther distances $(\mathrm{P}<0.003)$ (Table 3). Newborn death did not differ between those living close to high voltage power lines compared with those living farther away lines during pregnancy (Table 3).

Table 3

Adjusted OR for the association of preterm birth, birth defect, and newborn death with Distances from Power Lines during Pregnancy

\begin{tabular}{|l|c|c|c|c|}
\hline \multicolumn{1}{|c|}{ Variable } & Distance $(\mathrm{m})$ & $\mathrm{OR}^{\dagger}$ & $95 \%$ CI & P-values \\
\hline Preterm birth & $<600$ & 3.28 & $1.37,7.85$ & 0.008 \\
\hline & $\geq 600$ & 1.00 & & \\
\hline Birth defect & $<600$ & 5.05 & $1.52,16.78$ & 0.008 \\
\hline & $\geq 600$ & 1.00 & & 0.883 \\
\hline Newborn death & $<600$ & 0.847 & $0.093,7.746$ & \\
\hline & $\geq 600$ & 1.00 & & \\
\hline
\end{tabular}

${ }^{\dagger}$ Adjusted for parity, residence, educational status of men and women, and the job of men and women $(\mathrm{n}=288)$.

\section{DISCUSSION}

The high-voltage power lines in Iran provided a unique opportunity to assess associations of spontaneous preterm labor with magnetic fields generated by high voltage overhead power lines. This study is an important addition to research on the health affected by power lines. Only a few studies have investigated the pregnancy outcome affected by power lines, but the researchers showed that the electromagnetic field exposure of pregnant women did not increase the risk of pregnancy outcomes $[19,21-23]$. In this investigation, we found that women who were living in less than 600 meters from high voltage power lines had higher spon- taneous preterm birth and birth defects compared to those living farther than 600 meters. Meanwhile, numerous studies, which indicated an increased risk of cancers, and fetal loss $[17,24]$ in the women with exposure to magnetic fields generated by high voltage overhead power lines [25]. This could help to provide evidence for managing pregnant women who are at high risk of birth defect, and prevent preterm birth in pregnant women in prenatal services.

There are several limitations for this study: this study was based on the distance measured through geographical information systems (GIS), whereas future studies that use a means of a device for home measurements [26, 27] will provide all sources of magnetic fields in the residence [28]. 
However, distance data based on calculations using GIS data represent a perception of potential environmental hazards in epidemiological studies [29]. Another limitation of this nested case control study was that it was not possible to randomly assign pregnant women to live near or farther away from a high voltage overhead power line. This study could not analyze other risk factors that might influence the preterm birth. However, we controlled potential confounders of preterm birth such as living in urban and rural areas, demographic and socioeconomic status in the statistical analyses. Despite all the limitations, this study has important implications for future research and programs. The findings of this study may be used to minimize the adverse outcomes of pregnancy due to high voltage power lines.

\section{CONCLUSIONS}

These results add new important information about risk factor of preterm birth. Besides we found a significantly increased risk of spontaneous preterm birth in pregnant women, living in at least 600 meters from very high voltage (230 and 400 kilo volts). Therefore, installing overhead power lines and stations within 600 meters or making overhead underground would be useful in the prevention of preterm birth.

\footnotetext{
Acknowledgments. The authors acknowledge the assistance of Iranian women for their participation in this study, and the financial supporting of Babol University of Medical Sciences.
}

Conflict of Interests. The Authors declare that there is no conflict of interest.

Introducere. Asocierea dintre naşterea prematură şi expunerea la câmpuri magnetice este neclară însă expunerea uterului la undele electromagnetice se presupune a fi asociată cu naşterea prematură. Scopul studiului a fost de a evalua ipoteza asocierii dintre naşterea prematură şi locuința în apropierea unor linii de inaltă tensiune.

Materiale şi metode. A fost realizat un studiu caz-martor cuibărit într-o cohortă în care au fost analizate 135 de naşteri premature în spitalul Rohani din Babol, Iran în perioada 2013-2014. Martorii au fost 150 de naşteri la termen care au avut loc în acelaşi timp şi în acelaşi oraş şi au fost aleşi randomizat. Distanța până la cea mai apropiată linie de înaltă tensiune a fost determinată folosind softul ArcGIS. Pentru a testa legătura dintre expunere şi efect a fost realizată o analiză multivariată (regresie logistică).

Rezultate. La o distanță de cel mult 600 de metri au fost identificate 28 de locuințe (20 în grupul caz, 14.8\%) şi 8 in grupul martor (5.3\%). OR ajustat pentru naşterea prematură a fost mai mare la pacienții care locuiau la mai puțin de 600 de metri, $O R=5.05$, 95\% interval de incredere $1.52-16.78$ comparativ $\mathrm{cu}$ $O R=3.28,95 \%$ interval de incredere 1.37-7.85.

Concluzii. Amplasarea liniilor de înaltă tensiune ar trebui să se realizeze la mai mult de 600 de metri pentru a evita naşterile premature şi a defectelor de naştere.

Correspondence to: SEDIGHEH ESMAILZADEH, MD., Professor, Infertility and Reproductive Health Research Center,

Department of Obstetrics and Gynecology, Babol, Iran

Tel: (+98) 09124264633

E-mail: sesmael@yahoo.com

\section{REFERENCES}

1. GOLDENBERG RL, CULHANE JF, IAMS JD, ROMERO R. Epidemiology and causes of preterm birth. Lancet. 2008; 371(9606):75-84.

2. VAKILIAN K, RANJBARAN M, KHORSANDI M, SHARAFKHANI N, KHODADOST M. Prevalence of preterm labor in Iran: A systematic review and meta-analysis. Int J Reprod BioMed. 2015; 13(12):743-8.

3. SILBERGELD EK, PATRICK TE. Environmental exposures, toxicologic mechanisms, and adverse pregnancy outcomes. American journal of obstetrics and gynecology. 2005; 192(5 Suppl):S11-21.

4. FEIZI AA, ARABI MA. Acute childhood leukemias and exposure to magnetic fields generated by high voltage overhead power lines - a risk factor in Iran. Asian Pac J Cancer Prev. 2007; 8(1):69-72.

5. DE VOCHT F. Adult cancers near high-voltage power lines. Epidemiology. 2013; 24(5):782. 
6. DRAPER G, VINCENT T, KROLL ME, SWANSON J. Childhood cancer in relation to distance from high voltage power lines in England and Wales: a case-control study. Bmj. 2005 Jun 4; 330(7503):1290.

7. ELLIOTT P, SHADDICK G, DOUGLASS M, DE HOOGH K, BRIGGS DJ, TOLEDANO MB. Adult cancers near high-voltage overhead power lines. Epidemiology. 2013; 24(2):184-90.

8. KHEIFETS L, SWANSON J, GREENLAND S. Childhood leukemia, electric and magnetic fields, and temporal trends. Bioelectromagnetics. 2006; 27(7):545-52.

9. KROLL ME, SWANSON J, VINCENT TJ, DRAPER GJ. Childhood cancer and magnetic fields from high-voltage power lines in England and Wales: a case-control study. Br J Cancer. 2010; 103(7):1122-7.

10. PETRIDOU E, TRICHOPOULOS D, KRAVARITIS A, POURTSIDIS A, DESSYPRIS N, SKALKIDIS Y, et al. Electrical power lines and childhood leukemia: a study from Greece. Int J Cancer. 1997; 73(3):345-8.

11. SOHRABI MR, TARJOMAN T, ABADI A, YAVARI P. Living near overhead high voltage transmission power lines as a risk factor for childhood acute lymphoblastic leukemia: a case-control study. Asian Pac J Cancer Prev. 2010; 11(2):423-7.

12. SWANSON J. Childhood cancer in relation to distance from high-voltage power lines in England and Wales: a case-control study. J Radiol Prot. 2005;2 5(3):336-7.

13. MARCILIO I, HABERMANN M, GOUVEIA N. Extremely low-frequency magnetic fields and health effects: literature review. Rev Bras Epidemiol. 2009; 12(2):1-19.

14. BLAASAAS KG, TYNES T, LIE RT. Risk of selected birth defects by maternal residence close to power lines during pregnancy. Occup Environ Med. 2004; 61(2):174-6.

15. SAUNDERS RD, MCCAIG CD. Developmental effects of physiologically weak electric fields and heat: an overview. Bioelectromagnetics. 2005; Suppl 7:S127-32.

16. SAVITZ DA, ANANTH CV. Residential magnetic fields, wire codes, and pregnancy outcome. Bioelectromagnetics. 1994; $15(3): 271-3$.

17. LI DK, ODOULI R, WI S, JANEVIC T, GOLDITCH I, BRACKEN TD, et al. A population-based prospective cohort study of personal exposure to magnetic fields during pregnancy and the risk of miscarriage. Epidemiology. 2002; 13(1):9-20.

18. AUGER N, JOSEPH D, GONEAU M, DANIEL M. The relationship between residential proximity to extremely low frequency power transmission lines and adverse birth outcomes. J Epidemiol Community Health. 2011; 65(1):83-5.

19. DE VOCHT F, HANNAM K, BAKER P, AGIUS R. Maternal residential proximity to sources of extremely low frequency electromagnetic fields and adverse birth outcomes in a UK cohort. Bioelectromagnetics. 2014; 35(3):201-9.

20. POORTINGA W, COX P, PIDGEON NF. The perceived health risks of indoor radon gas and overhead powerlines: a comparative multilevel approach. Risk analysis : an official publication of the Society for Risk Analysis. 2008; 28(1):235-48.

21. MAHRAM M, GHAZAVI M. The effect of extremely low frequency electromagnetic fields on pregnancy and fetal growth, and development. Archives of Iranian medicine. 2013; 16(4):221-4.

22. GENEREUX M, AUGER N, GONEAU M, DANIEL M. Neighbourhood socioeconomic status, maternal education and adverse birth outcomes among mothers living near highways. J Epidemiol Community Health. 2008; 62(8):695-700.

23. ROBERT E, HARRIS JA, ROBERT O, SELVIN S. Case-control study on maternal residential proximity to high voltage power lines and congenital anomalies in France. Paediatric and perinatal epidemiology. 1996; 10(1):32-8.

24. LEE GM, NEUTRA RR, HRISTOVA L, YOST M, HIATT RA. A nested case-control study of residential and personal magnetic field measures and miscarriages. Epidemiology. 2002; 13(1):21-31.

25. BLAASAAS KG, TYNES T, IRGENS A, LIE RT. Risk of birth defects by parental occupational exposure to $50 \mathrm{~Hz}$ electromagnetic fields: a population based study. Occup Environ Med. 2002; 59(2):92-7.

26. MICHAELIS J, SCHUZ J, MEINERT R, MENGER M, GRIGAT JP, KAATSCH P, et al. Childhood leukemia and electromagnetic fields: results of a population-based case-control study in Germany. Cancer causes \& control : CCC. 1997; 8(2):167-74.

27. MCBRIDE ML, GALLAGHER RP, THERIAULT G, ARMSTRONG BG, TAMARO S, SPINELLI JJ, et al. Power-frequency electric and magnetic fields and risk of childhood leukemia in Canada. Am J Epidemiol. 1999; 149(9):831-42.

28. JAFFA KC, KIM H, ALDRICH TE. The relative merits of contemporary measurements and historical calculated fields in the Swedish childhood cancer study. Epidemiology. 2000; 11(3):353-6.

29. TURGEON A, BOURDAGES M, LEVALLOIS P, GAUVIN D, GINGRAS S, DEADMAN JE, et al. Experimental validation of a statistical model for evaluating the past or future magnetic field exposures of a population living near power lines. Bioelectromagnetics. 2004; 25(5):374-9.

Received January 17, 2017 